\title{
Examining Students' Self-Perceived Competence and Comfort in an Experiential Play Therapy Counseling Course: A Single Group Pretest-Posttest Investigation
}

\author{
Paulina Flasch \\ State University, San Marcos, TX, psf16@txstate.edu \\ Dalena Taylor \\ University of Central Florida, dalena.taylor@ucf.edu \\ Rikke Nynne Clauber \\ Community Practitioner, rikkeclauber@hotmail.com \\ Edward Robinson III \\ University of Central Florida, edward.robinson@ucf.edu
}

College of Education, Department of Counseling, Leadership, Adult Education \& School Psychology, Texas

Follow this and additional works at: https://digitalcommons.georgiasouthern.edu/ij-sotl

\section{Recommended Citation}

Flasch, Paulina; Taylor, Dalena; Clauber, Rikke Nynne; and Robinson, Edward III (2017) "Examining Students' Self-Perceived Competence and Comfort in an Experiential Play Therapy Counseling Course: A Single Group Pretest-Posttest Investigation," International Journal for the Scholarship of Teaching and Learning: Vol. 11: No. 1, Article 10.

Available at: https://doi.org/10.20429/ijsotl.2017.110110 


\title{
Examining Students' Self-Perceived Competence and Comfort in an Experiential Play Therapy Counseling Course: A Single Group Pretest-Posttest Investigation
}

\author{
Abstract \\ The current study utilized a single-group pretest-posttest design to evaluate students' self-perceived \\ competence and comfort of using a variety of play therapy techniques and interventions with a range of \\ client populations as a result of taking a one-week intensive course in Play Therapy. In an effort to \\ conduct course evaluation and explore student's self-perceived comfort and competence related to play \\ therapy the researchers created the Play Therapy Comfort and Competency Survey based on the content \\ of the course. The results indicated statistically significant scores between the pre- and posttest \\ measures, as measured by participants' self-perceived higher competence and comfort levels after taking \\ the course. Results from this preliminary study are promising as students' self-perceived competence and \\ comfort using play therapy was greater as a result of taking the one-week intensive MHS 6421 \\ Foundations of Play Therapy and Play Process course. Limitations of the study and implications for future \\ research are discussed.

\section{Keywords} \\ play therapy training, counselor preparation, course evaluation, self-efficacy, self-perceived competence

\section{Creative Commons License} \\ c) (i) $\ominus$ \\ This work is licensed under a Creative Commons Attribution-Noncommercial-No Derivative Works 4.0 \\ License.

\section{Cover Page Footnote} \\ Paulina Flasch, Department of Counseling, Leadership, Adult Education \& School Psychology, Texas State \\ University; Dalena Dillman Taylor, Department of Child, Family and Community Sciences, University of \\ Central Florida; R. Nynne Clauber, Community Practitioner, Orlando, Florida; E. H. "Mike" Robinson, \\ Department of Child, Family and Community Sciences, University of Central Florida. Correspondence \\ regarding this article should be sent to: Paulina Flasch, College of Education, Department of Counseling, \\ Leadership, Adult Education \& School Psychology, Texas State University, San Marcos, TX 78666. Email: \\ psf16@txstate.edu
}




\title{
Examining Students' Self-Perceived Competence and Comfort in an Experiential Play Therapy Counseling Course: A Single Group Pretest-Posttest Investigation
}

\author{
Paulina Flasch', Dalena Taylor Dillman², Rikke Nynne Clauber³, and Edward Robinson III2 \\ 'Department of Counseling, Leadership,Adult Education, and School Psychology, Texas State University, San Marcos, TX 78666, USA \\ ${ }^{2}$ Department of Child, Family, and Community Services, University of Central Florida, Orlando, FL 328I6, USA \\ ${ }^{3}$ Community Practitioner, Winter Park, FL 32792, USA
}

(Received 29 Februrary 2016;Accepted II November 2016)

\begin{abstract}
The current study utilized a single-group pretest-posttest design to evaluate students' self-perceived competence and comfort of using a variety of play therapy techniques and interventions with a range of client populations as a result of taking a one-week intensive course in Play Therapy. In an effort to conduct course evaluation and explore student's selfperceived comfort and competence related to play therapy the researchers created the Play Therapy Comfort and Competency Survey based on the content of the course. The results indicated statistically significant scores between the pre- and posttest measures, as measured by participants' self-perceived higher competence and comfort levels after taking the course. Results from this preliminary study are promising as students' self-perceived competence and comfort using play therapy was greater as a result of taking the one-week intensive MHS 642I Foundations of Play Therapy and Play Process course. Limitations of the study and implications for future research are discussed.
\end{abstract}

\section{INTRODUCTION}

Play therapy has become a significant therapeutic discipline addressing a wide range of presenting concerns and problems (Bratton, Ray, Rhine \& Jones, 2005; Lin \& Bratton, 2015). Further, play therapy is a versatile approach utilized with diverse populations in a variety of mental health counseling, school counseling, social work, and psychology settings (Kranz, Kottman, \& Lund, 1998; Kranz, Lund, \& Kottman, 1996; Phillips \& Landreth, 1995, 1998). Increased interest in the field of play therapy in recent years (Landreth, 20I2), combined with growing evidence-based support (Ray, Armstrong, Balkin, Jayne, 2015) calls for well-trained clinicians. Furthermore, developing knowledgeable and skilled clinicians begins with quality training. Thus, well-informed, evidence-based, and intentional instructional methodology appears vital to enhance counselors' qualifications (Jones \& Rubin, 2005; Yousef \& Ener, 2013). However, limited research exits related to best practices in training and development of competent play therapists in introductory or advanced settings. The goals of the present study were thus to examine students' self-perceived comfort and competency and to inform future course design and development and to address the need for evidence-based course evaluation in play therapy. This article presents an overview of (a) current trends in play therapy training and instruction, (b) the present study, and (c) implications for future research, training, and practice.

\section{Current Trends in Play Therapy Process and Training \\ Effectiveness of Play Therapy}

Play therapy is based on the belief that play is the language of children, and that toys are the words with which they express themselves and process current feelings and/or issues (Axline, 1947; Landreth, 20I2). Extensive research exists that demonstrates the effectiveness of play therapy as a therapeutic intervention (Bratton, Ray, Rhine \& Jones, 2005; LeBlanc \& Ritchie, 200I; Lin \& Bratton, 20I5) and will not be discussed at length in this article due to space limitations. It is, however, important to note that play therapy has been linked to positive outcomes regarding children's externalizing behaviors and relationships, attention deficit hyperactivity disorder, aggression, and teacher-child relationships (Bratton et al., 2005), in addition to greater academic achievement for young children (Blanco \& Ray, 20 I I). Several studies also illustrate that play therapy caters to the developmental needs of children and is effective with a diverse range of clients from various cultural and socioeconomic backgrounds (Bratton, 2010).

\section{Training Experiences}

Play therapy providers are required to obtain certain skills, attitudes, and specific knowledge (Association for Play Therapy [APT], 20I2); consequently, it is essential to provide training and play therapy courses that allows for the highest level of competence to be attained (Homeyer \& Rae, 1998). As others have highlighted, many practicing play therapists today have not had any explicit graduate school level training in play therapy (Phillips \& Landreth, 1995; Homeyer \& Rae, 1998). Results from Phillips' \& Landreth's study (1995) indicated that less than half ( $41 \%$ for females, $38 \%$ for males) of the play therapy practitioners surveyed had taken a graduate level course in play therapy. Instead, professional workshops were noted as the most common source of play therapy training. Ryan, Gomory, and Lacasse (2002) reported comparable results: approximately half $(53.5 \%)$ of the surveyed members of APT had some universitybased play therapy training. These findings emphasize the need for competent and adequate training, specifically at the university level, to ensure knowledgeable practitioners and the provision of quality play therapy services (Lindo et al., 20I2).

A growing number of universities presently offer courses and supervised experiences in play therapy (Homeyer \& Morrison, 2008). In fact, the number of universities in the United States that offer play therapy coursework has increased from 33 universities in 1989 to at least I7I universities in 201I (Landreth, 2012), with school counseling programs experiencing the most drastic increase compared to social work and psychology (Pascarella, 2012). However, while training programs are increasingly offering play therapy coursework, there is little regulation as to how student trainees are being trained, and whether the training programs increase students' play therapy competencies. In fact, Pascarella (2012) found that most training programs in the areas 

of school psychology, social work, and school counseling did not through various avenues, such as through experiences of mastery
provide enough training hours to meet minimum standards (APT, and modeling by others (Bandura, 1995). Larson and Daniels (1998) 2012; Landreth,, 2012). Thus, the present study aimed to add to the literature by evaluating a play therapy course and obtaining
essential information on students' self-perceived competence and comfort as a result of the course.

Pascarella (2012) found that the format and amount of training offered did not sufficiently prepare graduate students to use play
therapy competently and with confidence. Some of the main barriers to training include the lack of faculty with play therapy expertise as well as lack of time and space within the curriculum. In fact, other than standard requirements, no additional, play-specific credentials are required to teach play therapy coursework at the graduate level (Jones \& Rubin, 2005). It is encouraging, however, that the majority of graduate play therapy courses seem to be taught by instructors who are experts in play therapy. In fact, Jones and
Rubin (2005) examined play therapy coursework at 10 universities Rubin (2005) examined play therapy coursework at 10 universities
and found that of the instructors, $70 \%$ had terminal counseling and found that of the instructors, $70 \%$ had terminal counseling
or psychology doctoral degrees and $30 \%$ had Master's degrees in or psychology doctoral degres counseling or social work. In addition, $70 \%$ were Registered Play Therapists (RPT) or Registered Play Therapist-Supervisors Play The
(RPT-S).

Despite the growing number of play therapy programs, neter avilubility and accessibility of advanced graduated need for therapy courses (Jones \& Rubin, 2005; Kranz, Kottman, \& Lund 1998; Kranz, Lund, \& Kottman, 1996).

\section{Practitioner Self-Perceived Competence}

Self-perceived competence and comfort may be described as self-efficacy and refers to feelings or beliefs about one's ability to succeed at a given task or with a specific skill (Tang,Addison, LaSuresurprise that self-efficacy has received increased attention in recent years, as it is linked with effective practice and client outcome. In fact, McCarthy (2014) examined counselor trainees and found that increased levels of self-efficacy were associated with decrease levels of critical self-evaluation that negatively affected counseling sessions. Further, findings illustrated that students' self-efficacy in using counseling microskills (e.g., confrontation), and working with
difficult client situations (e.g., crisis) were positively correlated with difficult client situations (e.g., crisis) were positively correlated with
client outcome. Thus, coursework in practitioner-oriented fields client outcome. Thus, coursework in practitioner-oriented fields
typically aim to enhance student trainees' self-efficacy by targeting both theoretical and practical aspects (CACREP, 2009).

While researchers (e.g., Kozina, Grabovari, De Stefano, \& Drapeau, 2010) frequently focus on examining counselor selfBlount and Lambie (2015) used a longitudinal design to investigate Blount, and Lambie (2 $N$ ) Used a longitudinal design to investigate et al. 1996) over the course of three years. The researchers found that self-efficacy levels increased the most prior to clinical experience and not as a result of it Researchers (e.g. Bandura, 1956; 1977; 1995; Bowman \& Roberts, 1979) have also established a negative relationship between counselor anxiety and clinical judgment and performance, a relationship that can be mediated by increased performance, a relationship that can be mediated by increased
self-efficacy, which helps students cope with the anxiety that they eventually encounter during clinical training experiences (Larson \& explain that, in counseling, such experiences may be interpreted as modeling of counseling skills, experiential experiences, and affective rousal. Previous research findings thus suggest that self-efficacy is an important construct to examine in counselor trainees, including in play therapy coursework. Flasch, Bloom, and Holladay (2016) counselor trainees' experiences of self-efficacy in the core areas of counseling (CACREP, 2009), and found that trainees' experiences

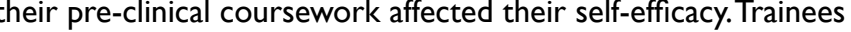
eported that experiential learning opportunities and modeling

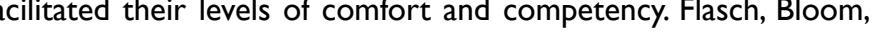
(2) also found that involving students in the

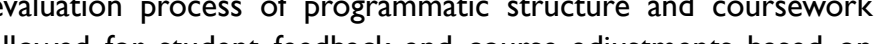
作

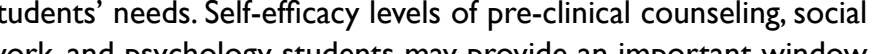
into how effectively they will eventually work with clients.

While play therapy has been utilized for over 100 years, there play therapist training issues. play therapist traning issues. To continue to establish and furcher on the training of competent professional play therapists (KaO \& Landreth 1997) and the evaluation of pay therapy training such as that at the university level The purpose of the present study was to address the need for course evaluation in play therapy training and to examine students' self-perceived learning from the present course. To achieve this, the researchers assessed the effectiveness of a graduate-level one-week intensive course in play therapy in regard to enhancing student's self-perceived comfort and competence utilizing play therapy, as measured by students' self-reported ratings. The aim was to provide the instructor with knowledge regarding the students' perception of competence to make data作 future semesters. The following research questions guided the and Compen of play therapy before and after participating in a play therapy class? (b) Do students experience increased competence related to using play therapy with different populations? (c) Do students experience enhanced understanding of specific play therapy techniques and Play Therapy Comfort and Competency Survey between participants who have no prior play therapy experience compared to those with prior experience? Based on previous literature on play (a) there would be a change in students knowledge of phy thent (a) there would be a change in students' knowledge of play therapy would experience increased competence related to using pay participants who have no prior play therapy experience compared to those with prior experience used a phenomenological methodology to examine pre-clinical Play Therapy Comfort and Competency Survey between participants therapy with different populations. (c) students would experience enhanced understanding of specific play therapy techniques and interventions, and (d) there would be a difference in overall scores on the Play Therapy Comfort and Competency Survey between

\section{METHODOLOGY}

The present study utilized a single-group pretest-posttest design play therapy, as a result of taking a graduate-level introductory play therapy, as a result of taking a graduate-level introductory
play therapy course in an accredited counseling program in
Southeastern United States.A survey questionnaire was developed and administered prior to and after the course's conclusion.

\section{Play Therapy}

The play therapy program housed at the researchers' local university consists of a four-course sequence that aligns with the criterion outlined by the Association for Play Therapy (APT), the accrediting body for registered play therapists (RPT). Applicants applying to become registered play therapists "must complete 150 hours of play therapy specific instruction from institutions of higher education..." (Guerrero \& Vega, 2014, p. 2) that must include (a) play therapy history (4-5 hours), (b) play therapy theories ( $40-50$
hours), (c) play therapy techniques and methods ( $40-50$ hours), and hours), (c) play therapy techniques and methods (40-50 hours), and (d) play therapy applications (40-50 hours). Each course offered covers approximately 67.5 contact hours of content as determined Therapy and Play Process course is the pre-requisie for the other three courses. the researchers were interested in its preparation of counselorsin-training specifically related to play therapy knowledge: therefore, in-training, specifically related to play therapy
this course is the focus of this investigation.

Foundations of play therapy. The Foundations of Play Therapy and Play Process course is an experiential counseling course taught by a professor and doctoral graduate assistants in the counselor education program. It is a Master's-level course offered to students and graduates as an elective, as a non-degree course, or as part of the play therapy certificate program. Its aim is to provide an experiential introduction to play therapy and to
teach students practical play therapy skills that can be used with children and adults. The course design is an intensive, one-week 40-hour format.

This course is intended as an introduction to the play therapy modality when working with children and families. The instructor provides (a) an introduction to the meaning of play in children's lives, (b) an overview of the stages of play in the therapeutic process, and (c) information on a variety of play and expressive art modalities. The main focus is on the modality of play; other expressive ar modalities are briefly covered (i.e., music, art, drama, dance, stories, poetry, games). Course objectives, as outlined in the syllabus, enable participants (a) to increase understanding of the process of play,

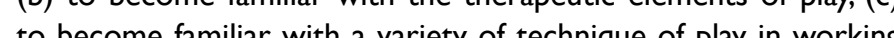
to become familiar with a variety of technique of play in working arts used in working with children, (e) to became familiar with the professional literature related to counseling through phy (I) to develop play experiences and play materials that can pe used with children in counseling and guidance, and (g) to develop an increased understanding of the interaction of media, therapeutic elements, technique and theory in counseling children. Over the course of the week, the instructor presents a variety of topics tha tie to the course objectives, such as (a) developmental aspects of play therapy, (b) therapeutic elements of play (c) using puppets, (d) psychodrama and sociodrama, (e) history of play therapy, (f) setting a a playroom, (g) limit setting and discipline, (h) finger painting (k) bibliotherapy, (I) using play dough, (m) filial therapy/parents' role, (n) using music, (o) dance therapy, (p) sandtray, (q) structured play therapy, (r) children's fear and stress, (s) cooperative and competitive games, (t) working with trauma, (u) using jokes, (v) sharing meaningful items, $(w)$ collaborative drawings, and $(x)$ reflections and closure.

\section{Participant Recruitment}

The researchers' Institutional Review Board (IRB) approved the present study. Participants were students in a single Play Therapy fourse in a large Southeastern, CACREP accredited institution. The for Wequents Play Therapy course and (b) provide consent to participate prior mpletion of the pre-survey.

Participants. Participants $(N=37)$ included (a) current Master's students $(n=27)$ pursuing counseling $(n=23)$, social work ( $n=3)$, and early childhood education ( $n=1)$ degrees, (b) certification in play therapy $(n=8)$ and non-degree seeking students $(n=2)$. Students who were Master's counseling students were in (ne of the following tracks ments helth colnseling (n $=14)$, school counseling $(n=5)$, and couples, marriage, and family
were counseling $(n=5)$. Three participants did not specify their track. Out of the 37 participants, 36 identified as female and one identified as male. Participants' ages ranged from 21 to 49 years old $(M=28.6$, $S D=8.2)$. Participants self-identified as belonging to the following ethnicities: Caucasian American $(n=14)$, Hispanic/Latina/o $(n=6)$, amaican $(n=3)$, Italian American $(n=2)$, African American $(n=$ 1), Argentinian American $(n=1)$, Asian $(n=1)$, Caribbean/African
American $(n=1)$, Danish $(n=1)$, Dominican/ltalian $(n=1)$, Jewish $(n=1)$, Pakistani $(n=1)$, and not specified $(n=4)$. Participants self-identified as belonging to the following racial categories:White/ Caucasian $(n=24)$, Black $(n=6)$, Asian $(n=3)$, Hispanic $(n=2)$, and mixed $(n=1)$. Out of the participants, $67.6 \%$ reported having no prior play therapy experience, $21.6 \%$ reported having prior play therapy experience, and $10.8 \%$ reported having had "some" prior play therapy experience.

Procedures

After obtaining approval from the Institutional Review Board (IRB) at the researchers' university, the primary researcher recruited start of the course. Participants we give class, pior to the A re the course. Participants were given informed consent. participate. The researcher administered the Play Therapy Comfort and Competency Survey within the first hour of the first day of the class, and again within the last hour of the last day of class. To maintain confidentiality and privacy of the participants, responses were voluntary and anonymous. For matching purposes, students were asked to list a private four-digit code on the pretest and osttest. The researchers matched surveys prior to data analysis.
Instruments. The researchers created the Play Therapy Comfort and Competency Survey, based on the class content, to 
evaluate participants' self-perceived competence and comfort/ self-efficacy using play therapy techniques with a range of client
populations, as a result of taking the Foundations of Play Therapy populations, as a result of taking the Foundations of Play Therapy
and Play Process course. The purpose for the development of this course-specific survey was to obtain a baseline of participants' competence and comfort/self-efficacy with play therapy skills to self-efficacy in the current course to make data-informed decisions regarding future semesters. The researchers asked the participants to rate, on a 5-point Likert scale, their self-perceived comfort and competence using specific play therapy techniques and using play therapy with various client populations. At the end of the survey participants were asked to complete a demographic questionnaire,
which included basic demographic information, their educational status, and their previous experience with play therapy. The Play Therapy Comfort and Competency Survey included the following sections: (a) comfort using various play therapy interventions with children, (b) comfort using various play therapy interventions with
adults, (c) knowledge and understanding of various play therapy adults, (c) knowledge and understanding of various play therapy
techniques and interventions, (d) comfort using play therapy with techniques and interventions, (d) comfort using play therapy with
various age groups, (e) comfort using play therapy with various diverse populations, and (f) comfort using play therapy to address various dagnoses based on the Dagnostic and Statistical Manu illustrates sample items from each section of the survey.

\section{Data Analysis Procedures}

Once the pretests and posttests had been matched for the 37 participants, the researchers entered the data into a statistics software program (Statistical Package for the Social Science; SPSS) for data analysis. The researchers used a repeated measures analysis of variance (ANOVA) to compare between-group means in the following categories of the survey: (a) overall change, (b) comfort therapy interventions with adults, (c) knowledge and understanding of specific play therapy techniques and interventions, (d) comfort using play therapy with different age groups, (e) comfort using play therapy with diverse populations, and (f) comfort using play therapy to address various diagnoses based on the Diagnostic and Statistical Manual of Mental Disorders (DSM), 5th Edition. Furthermore, the researchers aimed to investigate whether there was a difference in scores between participants with no prior play therapy experience compared to those with prior experience. An a priori power analysis indicated that 24 participants were needed to have $95 \%$ power for detecting a medium sized effect when employing a .05

\section{RESULTS}

The researchers used one-way analysis of variance (ANOVA) to explore the significance of change, if any, for students prior to and significance was set at 05 . Table 2 represents a sum

Research Question I: Is there an overall change in students' comfort and knowledge of play therapy before and after participating in a play therapy class?

Examining the overall scores of the Play Therapy Comfort and

Competency Survey (sections a-f), the effect of the play therapy training was statistically significant $\left(F_{1,36}=71.27, p<.05\right)$ between 78). Practical significance using Eta Squared indicated that $66 \%$ (n) $=.66$ ) of the difference in scores could be accounted for by the play therapy course, demonstrating a large effect size (Pierce, Block, \& Aguinis, 2004). Clinical significance indicated that out of the 37 participants, 34 participants $(91.9 \%)$ increased their comfort and competence level, with a range of -.67 to 15.17 and an average increase of 5.42 points $(S D=3.83)$. The findings supported the esearchers' 4 phothesis that there would be an overall change in students' comfort and knowledge of play therapy before and after participating in a play therapy class.

Research Question 2: Do students experience increased comfort and competence related to using play therapy with different populations? Related to the construct measuring students' comfort with play therapy interventions with children, there was a statistically .95) and difference in scores between the first $(M=2.39, S D$ Therapy Confort and Comptency Survey $\left(F_{1,36}=43.96, p<.05\right)$. Therapy Comfort and Competency Survey $\left(F_{1,36}=43.96, p<.05\right)$.
Practical significance using Eta Squared indicated that $55 \%(\mathrm{n} 2=$ 55) of he differe in scores colld be accourte for by te ply therapy course, de in strating a lore effect size (Pierce, Block \& Aguinis 2004), Clinical significance indicated that out of the 37 Agrticipants 37 particants $(100 \%)$ increas the out of the 37 play therapy interventions with childen, wh a range of 1.09 to play therapy interventions with children, with a range
3.82 and an average increase of 2.39 points $(S D=.95)$. In the survey subsection comfort with play therapy interventions with adults, there was a statistically significant difference in scores

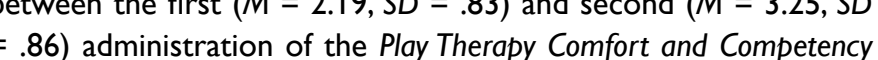
Survey $\left(F_{1,0}=60.1, p<.05\right)$. Practical significance using Eta Squared indicated that $63 \%(\eta 2=.63)$ of the difference in scores could be accounted for by the play therapy course demonstrating a large (Tizect (Perce, Block, \& Aguinis, 2004). Clinical significance

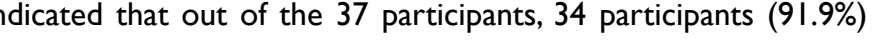
Wheased their comfort with play therapy interventions with adults, $(S D=.83)$

Related to the construct measuring students' comfort using play therapy with different age groups, there was a statistically 73) and difference in scores between the first $(M=2.19, S D=$ Therapy cocond $(M=3.07, S D=.91)$ administration of the Play Therapy Comfort and Competency Survey $\left(F_{1,36}=37.84, p<.05\right)$. $(n=5)$ of the difference in scores can be accounted for by time ( $22=.5)$ of the dife wence in scores an be accoun tor by time Aguinis, 2004). Clinical significance indicated that out of the 37 participants, 32 participants $(86.4 \%$ ) increased their comfort using play therapy with different age groups, with a range of -82 to 236 play therapy with different age groups, with a range
and an average increase of 0.88 points $(S D=.87)$.

In the survey subsection, students' comfort using play therapy to address different Diagnostic and Statistical Manual (DSM) for Mental scores between the first $(M=2.25, S D=1.08)$ and second $(M$ $=2.94, S D=.94)$ administration of the Play Therapy Comfort and
Competency Survey $\left(F_{1,36}=24.78, p<.05\right)$. Practical significance using scores can be accounted for by time (the intervention), demonstrating a large effect size (Pierce, Block, \& Aguinis, 2004). Clinical significance indicated that out of the 37 participants, 28 participants $(75.7 \%)$ increased their comfort using play therapy to address different DSM diagnoses, with a range of -47 to 3.07 and an average increase of 0.69 points $(S D=.84)$. The findings supported the researchers' hypothesis that students would experience increased comfort and competence related to using play therapy with different populations, as a result of the course.

Research Question 3: Do students experience enhanced knowledge and understanding of specific play therapy techniques and interventions? In the survey subsection knowledge and understanding of specific play therapy techniques and interventions, there was a statistically significant difference in scores between the first $(M=2.11, S D=.82)$ and second $(M=3.28, S D=.76)$ administration of the Play Therapy Comfort and Competency Survey $\left(F_{1,36}=79.23, p<.05\right)$. Practical significance using Eta Squared indicated that about $69 \%(\eta 2=.68 .8)$ course demonstrating a large effect size (Pierce, Block \& A Auinis, 2004). Clinical significance indicated that out of the 37 participunis, 35 participants $(94.6 \%$ increased their knowledge and understanding of specific play therapy techniques and interventions, with a range of -45 to 3.91 and an average increase of 1.17 points $(S D=80)$. The findings supported the researchers' hypothesis that students would experience enhanced knowledge and understanding of specific play therapy techniques and interventions as a result of the course.

Research Question 4: Is there a difference in scores between participants who have no prior play therapy experience compared to those with prio experience?

There was a statistically significant difference in scores between the first and second administration of the survey of the students who had no prior play therapy experience $(n=25 ; M=.70, S D=.67)$, compared to the students who had at least some prior play therapy experience $(n=11 ; M=.45, S D=.52), \mathrm{F}_{1,34}=25.63, p<.05$. Previous play therapy experience accounted for $43 \%(\eta 2=.43)$ of the difference in scores, indicating a large effect size (Pierce, Block, \& Aguinis, 2004). ne student did not provide an answer to this question.

Furchermore and consistent with the researchers' hypothesis, statistically significant findings indicated that students who had no prior play therapy experience started at a lower level of comfor students who had at least some previous play therapy experien did $=291, S D=54$ ) Prior phy therapy experience was self-reported $(M$ categorized by researchers as either no experience or some experience due to the subjective nature of students' experiences In addition, students who had no prior play therapy experience indicated they felt less comfortable and knowledgeable at the end of the course $(M=$ $3.18, S D=.81)$ than did students who had at least some previous play therapy experience $(M=3.35, S D=.60)$. However, both groups were found to have a statistically significant increase in their knowledge and comfort overall. The findings supported the researchers' hypothesis that there would be a difference in scores between participants who ad no prior play therapy experience compared to those with prior a result of participating in the course.

\section{DISCUSSION}

Approximately half of all registered play therapists have completed at least some university-level play therapy training (Phillips \& Landreth, (2012) Ryan, Gomory, \& Lacasse, 2002); however, Lindo and colleagues (2012) emphasized the need for this level of training to produce research has been conducted that assesses the quality of the training or participants feelings of competence and self-efficacy regarding their ability to apply the skills and knowledge obtained from such training. Mullen and colleagues (2015) recommended assessing selfperceived competence prior to clinical work given that students who have higher competence tend to perform better in their clinical work and have increased clinical judgment (Bandura, 1995). Therefore, the researchers of the present study aimed to evaluate the effectiveness of a play therapy course and explore participants' self-perceived competence and comfort/self-efficacy as a result of participating in

Overall, the intense modality (e.g., one week, 40-hour course) bility to use bery tcial in afecting participants beliefs about their populations. There were large effects of change in (a) particants cores from pre- to post- test regarding their knowledge of play therapy; (b) increased competence in using play therapy with different populations, such as children, adults, across age groups, and with different DSM diagnoses; and (c) enhanced knowledge with play therapy interventions. Majority of the participants in the present study $(n=34$ of 37) identified increased self-perceived competence, or self-efficacy. In line with previous studies (e.g., McCarthy, 2014), participants may also have experienced less negative self-perception (although not directly measured in this study). This finding has been found to affect counseling sessions less (McCarthy, 2014). Further, the increase in participants' self-perceived competence and comfor or self-efficacy, supports previous research specifying that with knowledse and practice alone, and without clinical experience, selfefficacy is increased (Mullen et al., 2015). The Council for Accreditation counseling and Related Educational Programs (CACREP, 2009) consicters it best practice to target both theoretical and practical aspects prior to clinical experience, which was utilized and supported the present study

Participants' self-perceived competence varied depending on the specific topic that was assessed. Since the course emphasized play therapy with children, it appeared logical that the largest clinical competence of using play therapy interventions with children, whereas only $75.7 \%(n=28)$ of participants reported increased self-perceived competence for using play therapy with clients with various DSM diagnoses. The instructor for the course covered DSM diagnoses and special populations in a portion of the course but the DSM topic was not infused throughout the course. Further, participants reported high levels of self-perceived competence in the following areas: (a) specific play therapy interventions $(n=35 ; 94.6 \%)$; (b) different age groups $(n=32 ; 86.4 \%)$, and (c) play therapy interventions with adults
$(n=34 ; 91.9 \%)$. Therefore, the aforementioned topics appeared to be covered adequately in the course, and participants felt comfortable with the knowledge they gained. 
As hypothesized, all participants' self-perceived competence of effective content and teaching methods for play therapy,although most play therapy increased; however, participants with no prior play therapy play therapy training. Additionally, individuals with no previous play experience indicated less comfort than those who had previous play therapy experience; although both groups increased in their comfort level. These findings seemed to illuminate researchers' (e.g., Mullen
et al., 2015) previous findings that suggest the greatest increase in counselor self-efficacy occurs prior to clinical experience. However the present study did not take into consideration participants previous intervals of self-efficacy increases, and can therefore not draw conclusions as to overall programmatic self-efficacy increases regarding pre- and post- clinical work. Regarding play therapy, prior play therapy experience appeared to be an important aspect of

Whe and comfort for the current participants.

While not identified as a research question, the findings of the present study also highlighted the evident difference between selfperceived comfort and self-perceived competency. Tang and colleagues (2004) described self-efficacy as feelings or beliefs regarding one's ability to use an acquired skill, suggesting in the definition that selfthe ry is a combinetor of comfort and competence. However perceived knowledge regarding play therapy (es competence) and their self-perceived comfort (eg, ability to use the skills) differed comparab constructs. Future research may focus on exploring the differences between these construct as they pertain to self-efficacy.

\section{Implications}

Course Specific. The findings of the present study provide useful insights into further enhancing the Foundations of Play Therapy and Play Process course content and promoting the continuation of
scholarship of teaching. Drawing from current findings, the instructor can be confident in the students' increased self-efficacy (i.e.. competence and comfort) of play therapy. The majority of participants in the present study believed that they felt comfortable using the knowledge obtained in the course. Participants in the present study experienced the least amount of self-efficacy increase in their ability to apply play therapy with clients with various DSM diagnoses. Based on the need for diagnoses in the mental health field, the instructor will aim to increase course content of DSM diagnoses and infuse this material throughout the curriculum. In future research, the curren instructor will also follow the participants across the four-course certificate program sequence to determine if students' self-perceived
competence and comfort in the present course affects students'

competence and comfort in the present course
ability to use play therapy skills in clinical practice.

in tay then to particy for assessing the quality of instruction (Lindo et at, 2012; Yoed a assessing the quality of instruction (Lindo et al., 2012, Youse curriculum as it aligns with the Associntion for Play Therap's (APT, 2012) Best Practices in subsequent offerings of the course. Future research will begin to answer the call of current practitioners that emphasize a continuing evaluation of current university-based play therapy courses (Joiner \& Landreth, 2005; Yousef \& Ener, 2013; Lindo et al., 2012). Continual evaluation is needed to ensure that instructors are meeting the needs of their students as well as closing

https://doi.org/10.20429/ijsotl.2017.110110 play therapy courses consist of a mixture of experiential and lecture 2005p). Therefore it is essential to emphasize the play (Jones \& Rubi of standards for best practice and criteria for the training of skilled play therapists, so they can be fully equipped and prepared to work with various populations (Joiner \& Landreth, 2005; Lindo et al., 2012; Yousef \& Ener, 2013). It behooves the field of play therapy to continu evaluating current courses and integrating new research findings, bes evidence-based practices, instructors should challenge themselves to conduct continual evaluations and implement those findings into their course teachings to enhance the learning of the students. Additionally, future research should examine different pedagogies of instruction (i.e., experiential, constructivist) to determine if students' perception of competence and comfort (i.e., self-efficacy) appears consisten across teaching styles. As mentioned previously, it may also benefit researchers to examine various components of self-efficacy, as the present study suggested a small discrepancy between comfort an we wh another group of participants to assess their levels of self-efficacy revious literarure (e McCarthy, 2014), individuals with higher selfompetence have been found to experience decreased negaive validated instruments exist that measure self-efficacy in conselors the play therapy field to explore avenues for instrument development regarding counselor self-efficacy using play therapy interventions and techniques. Future research should also examine if participants increased knowledge and competence make a clinical difference in clients, potentially examining outcome measures of clients.

\section{Limitations}

Because the sample size was smaller as a result of the intactness of one class, the findings are not generalizable. However, the researchers examined practical and clinical significance to create meaning from the statistical findings, which provided insight into future research. In adicion, we conducted an a priori analysis and determined the sample size exceded the minimum requirement to trust the findings for folly on self-report; however, use

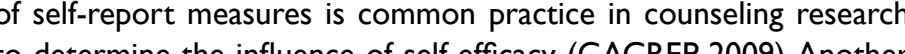
posttest While the couse was an intensive ween the pre- and postest. Whle the course was an intensive course comprising 40 one week. While the researchers' results indicated significant change fter a week, it may have been helpful to administer the survey a third ime after the course had concluded to examine the scores after some time had lapsed. Another limitation was that all participants in the sample were graduate-level students in the fields of counseling social work and psychology Students in such fields are well-educated on research and may have had increased awareness as to the have influenced the results. Lastly, the survey was developed by the authors to evaluate the current course; therefore, no psychometric properties are available, potentially introducing reliability and validity issues to the findings. However, anecdotally, participants' competence and comfort increased as a result of the Foundations of Play Therapy practices, and students' needs into each course. As the field moves to self-evaluation and decreased negative client outcomes. While (Counselor Self-Efficacy Scale [CSES]; Melchert, 1996), it may beneft imiterion ine of self-efficacy (CACREP, 2009). Another researchers' purpose of the present study. Thus, their responses may have been influenced by this awareness. Social desirability may also the Play Process course, making the study an important spring-board for future investigations

\section{Conclusion}

The purpose of the present study was to evaluate students' selfperceived competence and comfort of play therapy techniques and interventions, as a result of participating in a one-week intensive course in Play Therapy. The researchers hoped to utilize findings inform future play therapy courses. The experiential nature of the Foundations of Play Therapy and Play Process course indirectly increased participants' self-efficacy; therefore, the structure of the course (I-week long intensive training) appeared to be effective at increasing this group of students' competence in skills, knowledge, and comfort across populations over time. The present course was reported feeling competent as they progressed through the course, prior to seeing clients. The instructor gained valuable insight into aspects of the course that appeared to be covered well and those content areas which could be expanded. This current study provided the call for evaluation of current university-b be lean (

\section{REFERENCES}

Association for Play Therapy [APT] (2012). Play therapy best practices. Retrieved January 15, 2016 from http://c.ymcdn.com/sites/www. a4pt.org/resource/resmgr/Publications/Play_Therapy_Best a4pt.org/resour

Axline,V. (1947). Play therapy. Cambridge, MA: Houghton Mifflin.

Bandura, A. (1956). Psychotherapist's anxiety level, self-insight, an psychotherapeutic competence. Journal of Abnormal and Social Psychology, 52, 333-337. doi:10.1037/h0043075

Bandura,A. (1977). Self-efficacy: Toward a unifying theory of behavio change. Psychological Review, 84, 191-215.

Bandura, A. (1995). Self-efficacy in changing societies. New York, NY: Cambridge University Press.

Blanco, P.J., \& Ray, D.C. (20II). Play therapy in elementary schools A best practice for improving academic achievement. Journal of Counseling \& Development, 89, 235-240.

Bowman, J. T., \& Roberts, G. T. (1979). Counselor trainee anxiety during counseling. Journal of
$10.1037 / 0022-0167.26 .1 .85$

Bratton, S. (2010). Meeting the early mental health needs of children through school-based play therapy: A review of outcome therapy (2nd A. D 17-59). Hebch N Wil.

Bratton, S. C., Ray, D., Rhine, T., \& Jones, L. (2005). The efficacy of play Bratton, S. C., Ray, D., Rhine, T., \& Jones, L. (2005). The efficacy of play
therapy with children: A meta-analytic review of treatment ourcomes. Profession: A Psycholgy: Research and Pracice, 36(4) 376-390. Council for Accreditation of Couns for acceditation Alexandria VA: Prograns

Flasch, P., Bloom, Z., \& Holladay, K. (2016). Self-efficacy of counselor trainees in pre-practicum: A phenomenological study. Journal of traines in pre-practicum: $A$ Practice, $7(I), I-20$ designed to prepare students for future play therapy classes. Students
Homeyer, L. E. \& Morrison, M. O. (2008). Play therapy: Practice, issues, and trends. American Journal of Play, I (2), 210-228.

neyer, L. E. \& Rae, A. (1998). Impact of semester length on play therapy training. International Journal of Play Therapy, 7(2), 37-49.
a.r. \& Landreth, G. (2005). Play therapy instruction: A model based on objectives developed by the Delphi technique. International Journal of Play Therapy, 14, 49-68.

nes, L. \& Rubin, L. (2005). PT I0I: Teaching introduction to play therapy at the graduate level. International Journal of Play Therapy 14(I), 117-128.

, S-C. \& Landreth, G. L. (1997). Evaluating the impact of childcentered play therapy training. International Journal of Play Therapy (6) 2, I-20.

Mezina, K., Grabovari, N., De Stefano, J., \& Drapeau, M. (2010). Measuring changes in counselor self-efficacy: Further validation and implications for training and supervision. The Clinical Supervisor, 29, I17-127.

Kanz, P., Kottman, T., \& Lund, N. (1998). Play therapists' opinions concerning the education, training, and practice of play therapists. Imemational Journal of Play Therapy, 7, 73-8.

Phy the $N$, \& Korse play therapy course or program into a graduate curriculum andreth, $G$ L (2012) Play they:The Art of the

of the Relationship (3rd ed). New York, NY: Brunner Routledge.

son, L. M., \& Daniels, J. A. (1998). Review of the counseling selfefficacy literature. The Counseling
doi: $10.1177 / 0011000098262001$

LeBlanc, M., \& Ritchie, M. (2001). A meta-analysis of play therapy outcomes. Counseling Psychology Quarterly, 14, 149-163.

Lin, Y., \& Bratton, S. C. (2015). A Meta-Analytic Review of ChildCentered Play Therapy Approaches. Journal of Counseling \& Development, 93(I), 45-58. doi: 10.1002/j.1556-6676.2015.00180.x

indo, A. A, Chung, C-F., Carlson, S., Sullivan, J. M., Akay, S. \& MeanyWalen, K. K. (2012). The impact of child-centered play therapy training on atitude, knowledge, and skills. International Journal of Play Therapy, 2I (3), 149-166.

McCarthy,A. K. (2014). Relationship between rehabilitation counselor efficacy for counseling skills and client outcomes. Journal of Rehabilitation, 80(2), 3-11.

Melchert,T. P., Hays,V. L.,Wiljanen, L. M., \& Kolocek,A. K. (1996).Testing models of counselor development with a measure of counseling self-efficacy.Journal of Counseling \& Development, 74, 640-644. len, P. R., Uwamahoro, O., Blount, A. J., Lambie, G. W. (2015). Development of counseling students' self-efficacy during Pascarella, C. B. (2012) Play therapy training among school psychology, social work, and school counseling graduate training programs
(Unpublished doctoral dissertation). Alfred University. Alfred, New York.

Phillips, R. D. \& Landreth, G. L (1995). Play Therapists on Play Therapy I.: A Report of Methods, Demographics and Professional Practices. International Journal of Play Therapy, 4( I), I-26.

Phillips, R., \& Landreth, G. (1998). Play therapists on play therapy II: Clinical issues in play therapy. In

Pierce C.A., Block, C.A. \& Aguinis, H. (2004). Cautionary note on reporting eta-squared values from multifactor ANOVA designs. 
Educational and Psychological Measurement 64(6), 916-924. Ray, D. C., Armstrong, S. A., Balkin, R. S., \& Jayne, K. M. (2015) Childcentered play therapy in the schools: Review and meta-analysis. Psychology in the Schools, 52(2), 107-123. Ryan, S. D., Gomory, T. \& Lacasse J. R. (2002). Who we are: Examinin International Journal of Play Therapy, (II) 2, II-4I.

Tang, M.,Addison, K. D., LaSure-Bryant, D., Norman, R., O'Connell,W \& Stewart-Sicking, J. (2004). Factors that influence self-efficacy of counseling students:An exploratory study.

Yousef, D. \& Ener, L. (2013). Multicultural considerations in graduate play therapy courses. International Journal of Play Therapy, 23, 90-
99.
Appendix A

\begin{tabular}{|c|c|c|c|c|c|c|}
\hline \multirow[t]{2}{*}{$\begin{array}{l}\text { Survey } \\
\text { Item }\end{array}$} & \multicolumn{6}{|l|}{ Survey Question } \\
\hline & $\begin{array}{l}\text { Please rate your level of comfort using the following play therapy } \\
\text { interventions with children: }\end{array}$ & $\begin{array}{l}\text { Not at all } \\
\text { comfortable }\end{array}$ & $\begin{array}{l}\text { Somewhat } \\
\text { comfortable }\end{array}$ & Comfortable & $\begin{array}{c}\text { Very } \\
\text { comfortable }\end{array}$ & $\begin{array}{l}\text { Completely } \\
\text { comfortable }\end{array}$ \\
\hline 1 & Puppets & 1 & 2 & 3 & 4 & 5 \\
\hline 2 & Sandtray & 1 & 2 & 3 & 4 & 5 \\
\hline \multirow[t]{2}{*}{3} & Bibliotherapy & 1 & 2 & 3 & 4 & 5 \\
\hline & $\begin{array}{l}\text { Please rate your level of comfort using the following play therapy techniques } \\
\text { and interventions with adults: }\end{array}$ & $\begin{array}{l}\text { Not at all } \\
\text { comfortable }\end{array}$ & $\begin{array}{l}\text { Somewhat } \\
\text { comfortable }\end{array}$ & Comfortable & $\begin{array}{c}\text { Very } \\
\text { comfortable }\end{array}$ & $\begin{array}{l}\text { Completely } \\
\text { comfortable }\end{array}$ \\
\hline 15 & Movement Therapy & 1 & 2 & 3 & 4 & 5 \\
\hline 16 & Expressive arts (e.g., clay, painting, collage) & $\mathrm{I}$ & 2 & 3 & 4 & 5 \\
\hline \multirow[t]{2}{*}{18} & Filial Play Therapy & 1 & 2 & 3 & 4 & 5 \\
\hline & $\begin{array}{l}\text { Please rate your level of knowledge and understanding of the following play } \\
\text { therapy techniques and interventions: }\end{array}$ & $\begin{array}{c}\text { Not at all } \\
\text { knowledge- } \\
\text { able }\end{array}$ & $\begin{array}{l}\text { Somewhat } \\
\text { knowledge- } \\
\text { able }\end{array}$ & $\begin{array}{c}\text { knowledge- } \\
\text { able }\end{array}$ & $\begin{array}{c}\text { Very } \\
\text { knowledge- } \\
\text { able }\end{array}$ & $\begin{array}{l}\text { Completely } \\
\text { knowledge- } \\
\text { able }\end{array}$ \\
\hline 30 & Music Therapy & $\mathrm{I}$ & 2 & 3 & 4 & 5 \\
\hline 31 & Drama techniques (e.g., sociodrama, psychodrama) & 1 & 2 & 3 & 4 & 5 \\
\hline \multirow[t]{2}{*}{32} & Boardgames & $\mathrm{I}$ & 2 & 3 & 4 & 5 \\
\hline & $\begin{array}{l}\text { Please rate your level of comfort using play therapy with the following age } \\
\text { groups: }\end{array}$ & $\begin{array}{l}\text { Not at all } \\
\text { comfortable }\end{array}$ & $\begin{array}{c}\text { Somewhat } \\
\text { comfortable }\end{array}$ & Comfortable & $\begin{array}{c}\text { Very } \\
\text { comfortable }\end{array}$ & $\begin{array}{l}\text { Completely } \\
\text { comfortable }\end{array}$ \\
\hline 34 & Infancy $(0-1$ year $)$ & 1 & 2 & 3 & 4 & 5 \\
\hline 36 & Play age ( $3-6$ years) & $\mathrm{I}$ & 2 & 3 & 4 & 5 \\
\hline \multirow[t]{2}{*}{39} & Early adulthood (20 - 39 years) & $\mathrm{I}$ & 2 & 3 & 4 & 5 \\
\hline & $\begin{array}{l}\text { Please rate your overall level of comfort using play therapy with the } \\
\text { following populations: }\end{array}$ & $\begin{array}{l}\text { Not at all } \\
\text { comfortable }\end{array}$ & $\begin{array}{l}\text { Somewhat } \\
\text { comfortable }\end{array}$ & Comfortable & $\begin{array}{c}\text { Very } \\
\text { comfortable }\end{array}$ & $\begin{array}{l}\text { Completely } \\
\text { comfortable }\end{array}$ \\
\hline 46 & Culturally/religiously different from you & $\mathrm{I}$ & 2 & 3 & 4 & 5 \\
\hline 47 & Non-English speaker & $\mathrm{I}$ & 2 & 3 & 4 & 5 \\
\hline \multirow[t]{2}{*}{50} & Someone with disabilities & $\mathrm{I}$ & 2 & 3 & 4 & 5 \\
\hline & $\begin{array}{l}\text { Please rate your level of comfort using play therapy to address the following } \\
\text { diagnoses (based on DSM-5 categories): }\end{array}$ & $\begin{array}{l}\text { Not at all } \\
\text { comfortable }\end{array}$ & $\begin{array}{l}\text { Somewhat } \\
\text { comfortable }\end{array}$ & Comfortable & $\begin{array}{c}\text { Very } \\
\text { comfortable }\end{array}$ & $\begin{array}{l}\text { Completely } \\
\text { comfortable }\end{array}$ \\
\hline 60 & Neurodevelopmental disorders (e.g, autism,ADHD, learning disabilities) & $\mathrm{I}$ & 2 & 3 & 4 & 5 \\
\hline 64 & Anxiety disorders & 1 & 2 & 3 & 4 & 5 \\
\hline 66 & Trauma and stressor-related disorders (e.g.,PTSD) & 1 & 2 & 3 & 4 & 5 \\
\hline
\end{tabular}


TABLE 2. Paired Differences using ANOVA with Group Means and Standard Deviations.

Subscales of the Comfort and Knowledge with Play Therapy Questionnaire, Group Means, and Standard Deviations

Pre-test

Post-test

Eta Squared

Points Increased

Overall difference in scores between pre- and post-test

\begin{tabular}{|c|c|c|c|c|}
\hline Group Mean & 2.37 & 3.36 & 0.66 & 0.99 \\
\hline SD & 0.78 & 0.78 & & \\
\hline \multicolumn{5}{|l|}{ Overall differences for those with previous play therapy experience } \\
\hline Group Mean & 2.91 & 3.35 & & 0.44 \\
\hline SD & 0.54 & 0.6 & & \\
\hline \multicolumn{5}{|c|}{ Overall differences for those with no previous play therapy experience } \\
\hline Group Mean & 2.48 & 3.18 & & 0.70 \\
\hline SD & 0.77 & 0.81 & & \\
\hline \multicolumn{5}{|l|}{ Play therapy with children } \\
\hline Group Mean & 2.39 & 3.35 & 0.55 & 0.96 \\
\hline SD & 0.95 & 0.82 & & \\
\hline \multicolumn{5}{|l|}{ Play therapy with adults } \\
\hline Group Mean & 2.19 & 3.25 & 0.63 & 1.06 \\
\hline SD & 0.83 & 0.86 & & \\
\hline \multicolumn{5}{|l|}{ Play therapy with different age groups } \\
\hline Group Mean & 2.19 & 3.07 & 0.51 & 0.88 \\
\hline SD & 0.73 & 0.91 & & \\
\hline \multicolumn{5}{|l|}{ Play therapy with diverse populations } \\
\hline Group Mean & 2.98 & 3.65 & 0.41 & 0.67 \\
\hline SD & 1.09 & 0.86 & & \\
\hline \multicolumn{5}{|l|}{ Play therapy with different diagnoses } \\
\hline Group Mean & 2.25 & 2.94 & 0.41 & 0.69 \\
\hline SD & 1.08 & 0.94 & & \\
\hline \multicolumn{5}{|c|}{ Knowledge and understanding of specific play therapy techniques and interventions } \\
\hline $\begin{array}{l}\text { Group Mean } \\
\end{array}$ & 2.11 & 3.28 & 0.68 & 1.17 \\
\hline SD & 0.82 & 0.76 & & \\
\hline
\end{tabular}

Note. $p<.05, N=37$

All results were statistically significant. Mean numbers based on scores on the Play Therapy Comfort and Competency Survey, with the value of I representing "Not at all comfortable/knowledgeable" and the value of 5 representing "Completely comfortable/knowledgeable." 